\title{
Stress Management: Understanding Stress ${ }^{1}$
}

\author{
Joe Pergola and Suzanna Smith ${ }^{2}$
}

Stress management begins with you. Your reaction to stressors is very important. Your response impacts how stressful situations will be to your body, mind, emotions and relationships.

The first step to managing stress is awareness. You have to be aware of the warning signs in your body that you are under stress. Then you can do something to stop stress.

\section{Signs of Stress}

How do you know you are stressed? You may be aware of certain patterns in how you react to too many demands. Take a look at the list below and identify any signs that you are under stress. Pay close attention to physical warning signs as these are often the first clues that you are stressed.

Table. Some Warning Signs of Stress

\begin{tabular}{|c|c|c|c|}
\hline Physical & Emotional & Behavioral & Cognitive/Thinking \\
\hline $\begin{array}{l}\text { Faster heart rate } \\
\text { Pounding heart } \\
\text { Higher blood pressure } \\
\text { Sweaty palms } \\
\text { Muscle tightness of the } \\
\text { chest, neck, jaw and back } \\
\text { Headache } \\
\text { Diarrhea } \\
\text { Constipation } \\
\text { Trembling or twitching } \\
\text { Stuttering } \\
\text { Nausea or vomiting } \\
\text { Sleep problems } \\
\text { Fatigue } \\
\text { Shallow breathing } \\
\text { Dryness of mouth and } \\
\text { throat } \\
\text { Being easily startled } \\
\text { Cold hands } \\
\text { Itching } \\
\text { Chronic pain }\end{array}$ & $\begin{array}{l}\text { Irritability } \\
\text { Angry outbursts } \\
\text { Depression } \\
\text { Jealousy } \\
\text { Restlessness } \\
\text { Anxiousness } \\
\text { Lower initiative } \\
\text { Less involvement with others } \\
\text { Tendency to cry } \\
\text { Lack of interest } \\
\text { Being critical of others or } \\
\text { yourself } \\
\text { Nightmares } \\
\text { Thinking about things over } \\
\text { and over again } \\
\text { Fewer positive feelings about } \\
\text { things }\end{array}$ & $\begin{array}{l}\text { Increased smoking } \\
\text { Aggressive behaviors, } \\
\text { (e.g. in driving) } \\
\text { More alcohol use } \\
\text { More drug use } \\
\text { Under- or over-eating } \\
\text { Carelessness } \\
\text { Withdrawal } \\
\text { Listlessness } \\
\text { Hostility } \\
\text { Accident -proneness } \\
\text { Nervous laughter } \\
\text { Doing things over and } \\
\text { over again } \\
\text { Impatience } \\
\text { Insomnia }\end{array}$ & $\begin{array}{l}\text { Forgetfulness } \\
\text { Preoccupation } \\
\text { Blurred vision } \\
\text { Errors in judging distance } \\
\text { Less or more fantasies } \\
\text { Lower creativity } \\
\text { Lack of concentration } \\
\text { Less productivity } \\
\text { Lack of attention to details } \\
\text { Thinking a lot about the past } \\
\text { Slower reactions } \\
\text { Less coordination } \\
\text { Trouble paying attention } \\
\text { Feeling bad about yourself } \\
\text { Lack of control or need too } \\
\text { much control } \\
\text { Little sense of meaning in life }\end{array}$ \\
\hline
\end{tabular}

1. This publication is FCS2080, one of a series of the Department of Family, Youth and Community Sciences, Florida Cooperative Extension Service, IFAS, University of Florida. First Publication: June 1989 as FCS2081. Reviewed: August 1999. Revised: January 2003. Reviewed by: Samuel Sears, associate professor, Clinical \& Health Psychology, University of Florida Health Science Center, Gainesville, 32611. Please visit the EDIS Web site at http://edis.ifas.ufl.edu

2. Joe Pergola, extension agent IV, Hillsborough County, Seffner; and Suzanna Smith, associate professor, Human Development, Department of Family, Youth and Community Sciences, and Florida Cooperative Extension Service, IFAS, University of Florida, Gainesville FL 32611

The Institute of Food and Agricultural Sciences is an equal opportunity/affirmative action employer authorized to provide research, educational information and other services only to individuals and institutions that function without regard to race, color, sex, age, disability, or national origin. For information on obtaining other extension publications, contact your county Cooperative Extension Service office. Florida Cooperative Extension Service / Institute of Food and Agricultural Sciences / University of Florida / Christine Taylor Waddill, Dean 


\section{What's Causing Stress?}

The next step is to identify the situations that are causing you to feel stressed. When you find yourself tied up in knots, emotionally or physically, ask yourself, "What has just happened that makes me feel this way?" "Does this person, place, event, or thing make me feel this way?" Then check the symptoms from the list in the table.

\section{Learning to Relax}

Learning to relax is a powerful way to stop stress. Practice these few simple steps to calm down.

$\checkmark \quad$ Take a few deep, cleansing breaths

$\checkmark \quad$ Take a break

$\checkmark \quad$ Walk and talk more slowly

$\checkmark \quad$ Keep your sense of humor and laugh!

There are also simple relaxation exercises you can do on the spot.

\section{Relaxation Exercises}

A brief relaxation activity requires as little as $60-90$ seconds. The objectives of these activities are to:

- Help you maximize relaxation techniques nature has provided your body.

- Teach you simple techniques to relax that you can use in a variety of situations.

- Help you improve your breathing and visualization skills.

Step 1. Sit in a passive, comfortable position. Although this position may be most conducive to relaxation, you can do brief relaxation standing, waiting for an appointment, lying down, or as you prepare for an anticipated stressful event.

\section{Step 2. Practice one or more of the following activities several times each day:}

\begin{tabular}{|c|c|}
\hline Deep breathing & exhale slowly, and tell all your muscles to relax \\
\hline \multirow[b]{3}{*}{ Whole-body tension } & say as you exhale, "I feel tension and energy flowing out of my body." \\
\hline & repeat the above exercise five or six times and you'll become more relaxed. \\
\hline & $\begin{array}{l}\text { tense every muscle in your body; stay with that tension and hold it as long as you } \\
\text { can without any pain. }\end{array}$ \\
\hline \multirow[b]{3}{*}{$\begin{array}{l}\text { Shoulder shrugs } \\
\text { and head rolls }\end{array}$} & slowly release the tension and very gradually feel it leave your body. \\
\hline & repeat three times. Notice how your feelings change. \\
\hline & $\begin{array}{l}\text { try to raise your shoulders up to your ears. Hold for the count of four, then drop } \\
\text { your shoulders back to normal position. }\end{array}$ \\
\hline \multirow{4}{*}{ Imagine air as a cloud } & $\begin{array}{l}\text { rotate your head and neck. Vary this by rotating your shoulders up, down, and } \\
\text { head and neck around first one way, then the other, then both at the same time. }\end{array}$ \\
\hline & open your imagination and focus on your breathing. \\
\hline & $\begin{array}{l}\text { as your breathing becomes calm and regular, imagine that the air comes to you } \\
\text { as a cloud it fills you and goes out. }\end{array}$ \\
\hline & Notice that your breathing becomes regular as you relax \\
\hline
\end{tabular}




\section{How Do You Look at Stress?}

Another important step in managing stress is to monitor how you look at or are thinking about the situation. What do you believe will happen? What do you think about your ability to deal with the problem?

Have you ever noticed that while one person sees a situation as a problem another views it as a challenge? The person's perspective on the situation may be more important than the objective situation. Research shows that adults who are optimistic have higher levels of mental and physical health than those who are more negative.

There seems to be a self-fulfilling prophecy at work: When you see a stressor as a problem or crisis it is likely to become a crisis because you feel unable to cope. But when you see an event as something that can be managed, you are likely to act quickly to solve a problem before it exhausts your available and reserve energy. In other words, how you perceive the situation influences how you react.

It is not clear what enables some people to "see a glass half full" while others see it "half empty." Outlook may be affected by the person's sense of autonomy and control. They feel independent and in charge of daily life. People who feel in control are more likely to believe they can handle a situation and are able to prevent it from becoming stressful. People who look at a situation as something they can handle are sure that it will be resolved and take steps to confront or solve the problem. This may prevent it from becoming worse. A loss of autonomy can be distressing and can hurt your emotional and physical health. On the other hand, maintaining autonomy can be beneficial.

In the later years of life, some events may decrease an older person's autonomy and control, such as retirement and reduced economic freedom, residential moves, and reduced mobility from physical impairments. Yet when older people are encouraged to do things for themselves, they maintain a sense of independence and physical health and express satisfaction with their lives.

Autonomy and control are also important for working people who often experience strains from long work hours and an assigned schedule. Control over the length and schedule of work hours seems to reduce feelings of helplessness and stress.

Although it is important to maintain autonomy and control, it may also be important to recognize when situations cannot be controlled. This avoids getting more frustrated and tense. What to do when a solution is out of reach? Change your outlook by "letting go" rather than forcing a solution. Another option is to reframe the situation, that is, to look at it in a different, more positive light. This technique often helps a person accept and feel better about the situation. Of course, there are times when reframing doesn't fit the situation. There are also times when it seems almost impossible to feel positive. It is important to accept these feelings as legitimate and valuable, too. Feeling sad, lonely, or afraid is not bad. With reflection and acceptance, even a problem may turn into an opportunity to learn and grow. At these times it may be helpful to take walks outdoors and to try to appreciate the positive aspects of your life.

\section{References}

Davis, M., E.R. Eshelman, and M. McKay. 1995. The relaxation and stress reduction workbook. Oakland, CA New Harbinger Publications, Inc.

International Stress Management Association. Calm down. Accessed June 1, 2002.

http://www.stress-management-isma.org/relax.html
Rose Men's health Resource. How to fight and conquer stress. Accessed June 14, 2002. http://www.coolware.com/health/medical reporter/stress.html Robinson, Jerry. 1982.Stress and How to Live With It. Cheryl Tevis (ed.). Des Moines: Meredith Corporation. 